UDC 71:349

DOI: $10.24045 /$ et.2017.1.13

\title{
AGGLOMERATION DEVELOPMENT PROBLEM IN RUSSIA
}

\author{
L. G. Selyutina \\ L. E. Biriukova
}

\author{
Doctor of Economical Sciences, professor \\ student \\ Saint-Petersburg State University \\ of Economics \\ Saint-Petersburg, Russia
}

\begin{abstract}
The article is dedicated to the review of the broaden circle of the actual questions in formation and regulation of urban agglomerations as one of the significant forms of territory organisation of economics and resettlement in Russia. The author researched the modern approaches to rational use and management of big territories on the base of interrelated development of the cities. It is emphasized that agglomeration only is the main trend in the development of megalopolises. It is showed that by using of the rational system of organisation indicators and town-planning processes it is possible to provide the reliable assessment of agglomerations in order to increase the efficiency of the complex urban development.
\end{abstract}

Keywords: territory; large city; developer; planning; real estate market.

The cities are the centers of the concentration of economic activity the basis of the country's development. In the cities there are held the main economic processes such as trade and production, increasing the GDP level. Even in the time of Roman Empire the towns represented the important centers, where the crafts and the trade concentrated. Roman Empire was famous by its town-planning and the large network of the roads, connected the towns with dependent territories. Right planning not even provided to the Empire the power for many years but also became one of the reasons of its fall because of the barbarians. Nowadays the towns continue to develop. And, if earlier the size of the town influenced positively its economics, nowadays the big cities become the concentration of the problems traffic jams, overcrowding, poverty and unemployment. Developing spon- taneously, many towns didn't form the efficient structure, which could solve the given problems. Here the agglomeration question occurs.

Agglomeration represents the urban structure, consisted of the core city and other towns near. In other words, agglomeration represents the socioeconomic system as the aggregate of different socio-economic variables, such as population density, population size, the level of the wages. According to the World Bank data the biggest agglomerations in the world are: Tokyo (38 million people), Deli (25,7 million people), Shanghai $(23,7$ million people). Among the Russian agglomerations Moscow is on the $22^{\text {nd }}$ place of the biggest agglomerations of the world. The size of Moscow is 12,2 million people. This is even more than London and Paris (less than 11 million people). 
The agglomeration problem might be easily explained by the law of diminishing returns, where the dependency between the agglomeration size and the efficiency of its functioning is shown. With the increase of the size of the agglomeration its efficiency is increasing, then - the bigger is the city, more is the economic effect from its activity. Though if develop the agglomerations purposefully, many problems may be solved and it is possible to attract more of qualified population for the territory development. The main advantage of purposeful growth is the returns to scale. The transport lines in this way are the part of the unified system, allowing the people from environs to get the access to the work in the city. Moreover, the production concentrates in one place, and the concentration of resources allows to direct the qualified personnel to the way of increase of efficiency of created economic system.

In the countries of European Union and in United States the agglomeration index is used for the purposes of agglomeration assessment, counted by the use of indicators of population size, population density and the time needed to come from the nearest areas to the core city. If analyze the given indicators in Russia it is possible to conclude about the following problems of agglomeration development. Firstly, the urban and rural population is allocated in the following way: $74 \%$ - the urban population, $26 \%$ - the rural population. This proportion does not change from 1985. Secondly, the population is distributed on the territory irregularly. That may be explained by the existence of the permafrost zones, where almost nobody lives, and also it might be explained by the historical development of central territories. At the moment the concentration of urban population in the federal districts of Russia is characterized by the large number of people living in the big cities - Moscow and Saint-Petersburg. In Moscow region $31 \%$ of urban population lives, in the Northwestern region $16 \%$. Thus the population from all the territories of Russia gradually migrates in the central regions. As one of the main reasons of such an irregular allocation it can be the different level of the wages in the central part of Russia and in the regions.

In the most of the Russian towns the wages are more than twice lower in comparison to Moscow. But the problem is not only in irregular allocation but also in social inequality of the population. The income level of the poorest $20 \%$ of population is in 16,5 times lower than the income level of $20 \%$ of the richest. This increases the social tension only. The agglomeration development problem must be solved in centralized way and should be presented in the strategies of regional growth. The planned development of transport system in the towns, the production development will allow to create more vacant positions in regions. This will increase the GDP level in the country, well than will influence the increase of the wages of working class. So, it is necessary to notice the successful projects of urban development, for example, Moscow development concept until 2030, connected mainly with the problem of transport traffic in the capital. It is planned to intercon- 
nect the spontaneously joined environs of Moscow by the network of roads.

As result, that should help to reduce the tension. The active development of remoted areas of Moscow will allow to improve the quality of life in these areas and hence will increase their attractiveness. The proposed concept has already won first places in European ratings dedicated to urban development and we can expect that by 2030 Moscow will become the agglomeration which is convenient for life. To conclude, it is important to say that the agglomeration development problem in Russia exists and this is connected with irregular allocation of the population in the territory of Russia, different level of the wages, and spontaneous growth of the towns. This finally leads to overcrowding, traffic jams, low income and low quality of life.

\section{Библиографический список}

1. Selyutina L. G., Bondar O. Y., Magomedragimov M. R. Actual aspects of the integrated approach to urban areas development // Paradigmata poznani. - 2016. № 1. - P. 30-31.

2. Ватченко Б. С. Оценка имущественного потенциала региона // Социосфера. 2013. - № 3. - C. 200-204.
3. Гольдберг А. Л. Развитие агломерационных процессов в России // Вестник развития науки и образования. - 2014. № 5. - C. 93-96.

4. Селютина Л. Г. Развитие реконструктивно-строительной деятельности по формированию инвестиционного предложения на российском рынке жилья // Kant. - 2016. - № 3 (20). C. $126-129$.

\section{Bibliograficheskij spisok}

1. Selyutina L. G., Bondar O. Y., Magomedragimov M. R. Actual aspects of the integrated approach to urban areas development // Paradigmata poznani. - 2016. № 1. - P. 30-31.

2. Vatchenko B. S. Ocenka imushhestvennogo potenciala regiona // Sociosfera. 2013. - № 3. - S. 200-204.

3. Gol'dberg A. L. Razvitie aglomeracionnyh processov v Rossii // Vestnik razvitija nauki i obrazovanija. - 2014. № 5. - S. 93-96.

4. Seljutina L. G. Razvitie rekonstruktivnostroitel'noj dejatel'nosti po formirovaniju investicionnogo predlozhenija na rossijskom rynke zhil'ja // Kant. - 2016. № 3 (20). - S. 126-129.

(C) Selyutina L. G., Biriukova L. E., 2017. 